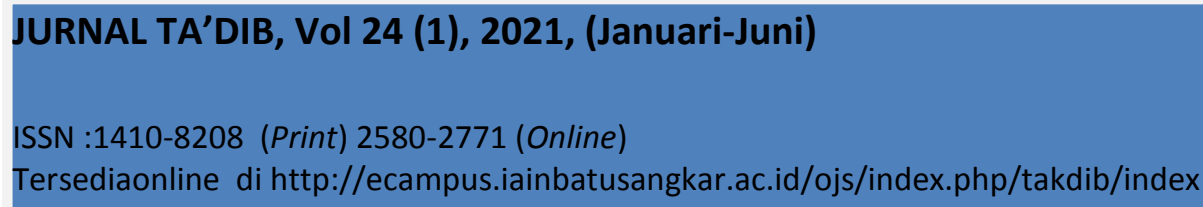

\title{
Curriculum Analysis of Master Program in Islamic Higher Education
}

Received: 01-12-2020; Revised:12-06-2021; Accepted: 15-06-2021

\section{Muhammad Munadi*)}

Tarbiyah Faculty, Surakarta State Institute of Islamic Studies, Sukoharjo, Central Java, 57168, Indonesia

Email:

muh.munadi@iainsurakarta.ac.id

\section{Noor Alwiyah}

Tarbiyah Faculty, Surakarta State Institute of Islamic Studies, Sukoharjo, Central Java, 57168, Indonesia

Email: alwiyahnoor@yahoo.co.id

\section{Rustam Ibrahim}

Tarbiyah Faculty, Surakarta State Institute of Islamic Studies, Sukoharjo, Central Java, 57168, Indonesia

Email:

rustamibrahimalfatih@gmail.com

*) Corresponding Author

\begin{abstract}
The purpose of this research is to analyze the construction and content of the curriculum of Postgraduate, especially on Master Program in Islamic Religious Education at two Islamic Higher Education - private and public. The method used in this research is a descriptive qualitative method by focusing on curriculum construction and then analyzingit using content analysis. The results of this research show that the curriculum construction of the Master Program in Islamic Religious Education at UIN Maulana Malik Ibrahim and UNISMA Malang is based on the grouping of subjects according to the demands of the Indonesian National Qualification Framework at the 8 level. The curriculum content is mainly dominant in strengthening Pedagogical Content Knowledge (PCK). Second, Postgraduate does not provide alternative curriculum so there is no flexibility. Curriculum of the master program in Islamic Religious Education must be able to strengthen the content knowledge of Islamic education.
\end{abstract}

\begin{abstract}
Abstrak: Tujuan penelitian ini adalah untuk menganalisis konstruksi dan isi kurikulum Pascasarjana, khususnya Program Magister Pendidikan Agama Islam di dua Perguruan Tinggi Islam - swasta dan negeri. Metode yang digunakan dalam penelitian ini adalah metode kualitatif deskriptif dengan memfokuskan pada kontruksi kurikulumnya dan kemudian menganalisisnya dengan menggunakan analisisisi. Hasil penelitian menunjukkan bahwa konstruksi kurikulum Program Magister Pendidikan Agama Islam di UIN Maulana Malik Ibrahim dan UNISMA Malang didasarkan pada pengelompokan mata pelajaran sesuai tuntutan. Kerangka Kualifikasi Nasional Indonesia jenjang ke-8. Isi kurikulum terutama dominan dalam penguatan Pedagogical Content Knowledge (PCK). Kedua, Pascasarjana tidak menyediakan kurikulum alternative sehingga tidak ada fleksibilitas. Kurikulum program magister Pendidikan Agama Islam harus maтри memperkuat muatan pengetahuan pendidikan Islam.
\end{abstract}

Keywords: Curriculum, Master, Islamic Religious Education, Content Knowledge.

\section{INTRODUCTION}

$\mathrm{T}$ The recruitment of teachers from undergraduate program does not necessarily improve the quality of
Islamic Religious Education learning (hereinafter referred to as PAI), and does not directly produce teachers who have competence according to applicable 
regulations. This is because the PAI department itself requires the basics of Islamic material that previously had to be studied specifically so that it becomes a solid basis to continue at the level of deepening. As data from 2011-2012 stated that 42\% came from SMA, 35\% from MA, $14 \%$ from Islamic boarding schools and the remaining 7\% from others. Meanwhile, in 2019 there were $55 \%$ from SMA and SMK, $41 \%$ from MA and the rest from Islamic boarding schools (Suwendi, 2019). The data shows that far more high school graduates continue their studies to PTKI, and this directly impacts the quality inputs in PAI study programs. PTKI under the Ministry of Religious Affairs (Kemenag) of the Republic of Indonesia, which until now has reached 577 (53 public and 524 private) institutions, mostly or around $90 \%$ carry out PAI Department/ Study Program.

The graduates of PTKI are mostly from the Department or Study Program of PAI. The competition is getting tougher because two public universities under the Ministry of Research and Technology and Higher Education have Islamic Studies Department. The two universities are the State University of Jakarta (UNJ) and the Indonesian University of Education (UPI). UNJ has Islamic Studies Study Program majoring at PAI, while UPI has a study program in Islamic Education Science (Munadi, 2017a). The needs for educators in educational institutions in this country such as in school, madrasahs, and pesantren, perhaps are not as much as the amount of PAI graduates. However, the PAI Department has already been known by the public to have a particular/promising future carrier than other departments at PTKI. This kind of situation makes quality control of its graduate neglected.

Besides, the so many graduates of PAI are frequently questionable in their quality. Even though the graduates are prepared to become PAI teachers in schools, and groups of PAI subject (Qur'an Hadith, Aqeedah and Morals, Fiqh, and History of Islamic
Civilization) in Madrasahs, they have not been able to meet the demands of schools and madrasahs fully. Not to mention the demands of PAI teacher candidates which is different between schools and madrasahs.

The need for general PAI teachers come from schools under the Ministry of Education and Culture, while the need for specific PAI teachers come from schools under the Ministry of Religious Affairs. From the aspect of national teacher standards, PAI teachers still do not meet the qualification standards; especially the provision of Government Rules (PP) No. 19 of 2006 concerning about National Education Standards article 29, stating that every educator at all levels must at least pass undergraduates or diploma IV (S1 / D-IV). In real terms, all these conditions have not been fulfilled yet. Table 1released by the Directorate General of Islamic Education (2010) shows:

Table 1. Islamic Education Teacher Condition Year 2009/2010

\begin{tabular}{|l|l|l|}
\hline Graduates & Amount & Percentage \\
\hline$<=$ S1 (undergraduate) & 93,032 & 52.3 \\
\hline$=$ S1 (undergraduates) & 82,441 & 46.4 \\
\hline$>$ S1(postgraduates) & 2,330 & 1.3 \\
\hline Total & 186,906 & 100 \\
\hline
\end{tabular}

There are still 93,032 PAI teachers who do not have a bachelor degree or around $52.3 \%$. The table 1 also shows that the majority of PAI teachers are undergraduate, and their mastery of study content in Madrasah Tsanawiyah is still weak, which is below 78 from the range of $0-100$ (Munadi, 2017b). The curriculum of preparing PAI teacher candidates at UPI focuses on the mastery of Islamic religious content rather than providing learning methodology material compared to PTKI (Munadi, 2017a).

The high percentage of PAI teachers who do not have bachelor and master degree makes the Ministry of Religion issue a strategic policy to improve quality, relevance, and competitiveness; by recruiting educators and education staffs based on qualifications and competencies 
(Kementerian

Agama,

2008).

College/university should consider those aspects by taking strategic steps, including further study and continuous training. Further study for the teachers, especially PAI teachers, can be seen in the curriculum.

The aspects of curriculum will determine the performance of graduates of educational institutions. According to Smith, cited by Hughes \& Tan, (2012) the curriculum has four alternative conceptions: as the transmission of knowledge; as a goal to be achieved (or products); as the interaction among teachers, student and knowledge (active processes); and as praxis - which escalates the process model to bring student and teacher's experiences into dynamic interactions of action and reflection. Research on the postgraduate curriculum conducted by Widodo (2013) shows the need for integration of the curriculum of Bachelor and Master of Education. That is because the Master Program is a continuation of the Bachelor curriculum.

The material discussed in Master Program is a deepening of the material studied in the undergraduate program, and lecturers teaching in the program should come from relevant field of studies. Research on postgraduate curriculum evaluation in Iran by (Beigi et al., 2011) shows that postgraduate curriculum evaluation must be an ongoing and dynamic process because it refers to: changes in technology and science, the evolution of economic, social, and cultural change, political change, and globalization. The development of the Master curriculum must answer society demands and scientific development. Therefore, this paper aims to find out the structure and content of the curriculum of Master Program in Islamic Education in private and public Islamic Universities.

\section{METHOD}

This research uses a descriptive qualitative approach. This study strives to find the meaning of curriculum in the Master Program in Islamic Religious Education
(PAI) in two universities that have a master's degree in PAI.

The primary data source comes from the official website of the two post-graduate master programs, namely: Master of Islamic Religious Education of State Islamic University (UIN) Maulana Malik Ibrahim Malang (hereinafter will be shortened to UIN MALIKI) as the representative of public universities, and Master of Islamic Education of Islamic University of Malang (Universitas Islam Malang, hereinafter will be shortened to UNISMA) as the representative of private universities. Data analysis techniques use content analysis supported by qualitative data. The purpose of this research is to analyze the construction and content of the curriculum of Master Program in Islamic Religious Education at two Islamic Higher Education - private and public.

\section{Findings and Discussion}

Data from the Directorate of Islamic Higher Education shows that the number PTKI which has a postgraduate program is 78. It consists of 43 State PTKI and 35 Private PTKI, as shown in the following data

Table 2. Amount of PTKI Having Master of Education Program

\begin{tabular}{|c|c|c|c|}
\hline $\begin{array}{c}\text { Master Study } \\
\text { Program }\end{array}$ & $\begin{array}{l}\text { State } \\
\text { PTKI }\end{array}$ & $\begin{array}{c}\text { Private } \\
\text { PTKI }\end{array}$ & Total \\
\hline $\begin{array}{ll}\text { Islamic } & \text { Education } \\
\text { Science } & \end{array}$ & 1 & 1 & 2 \\
\hline Tarbiyah Science & 1 & 0 & 1 \\
\hline $\begin{array}{l}\text { Management } \\
\text { Islamic Education }\end{array}$ & 4 & 7 & 11 \\
\hline $\begin{array}{l}\text { PAI (Islamic Religious } \\
\text { Education) }\end{array}$ & 20 & 9 & 29 \\
\hline $\begin{array}{l}\text { PBA (Arabic } \\
\text { Language Education) }\end{array}$ & 2 & 3 & 5 \\
\hline $\begin{array}{l}\text { PBI (English Language } \\
\text { Education) }\end{array}$ & 1 & 0 & 1 \\
\hline $\begin{array}{lr}\text { PGMI } & \text { (Madrasah } \\
\text { Ibtidaiyah } & \text { Teacher } \\
\text { Training) } & \\
\end{array}$ & 3 & 0 & 3 \\
\hline $\begin{array}{lr}\text { PGRA } & \text { (Raudlatul } \\
\text { Athfal } & \text { Teacher } \\
\text { Training) } & \\
\end{array}$ & 1 & 0 & 1 \\
\hline PI (Islamic Education) & 10 & 15 & 25 \\
\hline $\begin{array}{l}\text { Studi PI (Islamic } \\
\text { Education Study) }\end{array}$ & 1 & 0 & 1 \\
\hline
\end{tabular}




\begin{tabular}{|l|c|c|c|}
\hline \multicolumn{1}{|c|}{$\begin{array}{c}\text { Master Study } \\
\text { Program }\end{array}$} & $\begin{array}{c}\text { State } \\
\text { PTKI }\end{array}$ & $\begin{array}{c}\text { Private } \\
\text { PTKI }\end{array}$ & Total \\
\hline $\begin{array}{l}\text { Tradisi PI (Islamic } \\
\text { Education Tradition) }\end{array}$ & 1 & 0 & 1 \\
\hline Total & 45 & 35 & 80 \\
\hline
\end{tabular}

The Department of Islamic Religious Education in Master Program is relatively large, but there are 29 units directly related to PAI or approximately $37.5 \%$. The percentage of State PTKI was $25 \%$ while Private PTKI was $11.25 \%$. Thus, it illustrates that the number of PAI postgraduate study programs is relatively large compared to other majors.

There are not many programs that describe the real condition of their program on the internet so that this paper is limited to PTKIs that provide information on online media. Only seven from a total of 29 PAI graduate programs identified have relatively complete information on their website. It means that only $24.13 \%$ used information and communication technology (ICT) to advertise their product to the public. Research conducted by (Pyla, 2012) shows that ICTs act as agents of change in education and society by promoting the right balance between content generation, research in a relevant field relating to investing education and connectivity to integrate knowledge with the development in other countries. ICTs significantly contribute to productive learning and quality improvement in the education world (Anwar \& Mathew, 2014). Table 3 is the PTKI that holds postgraduate courses:

Table 3.Internet Application for Socialization of Postgraduate Program

\begin{tabular}{|l|c|c|}
\hline \multicolumn{1}{|c|}{ PTKI } & Amount & Percentage \\
\hline State PTKI & 3 & 42,85 \\
\hline Private PTKI & 4 & 57,15 \\
\hline Total & 7 & 100 \\
\hline
\end{tabular}

The table 3 shows that there are very few postgraduate programs making use of the internet for information access. This condition hinders those universities from developing their potential and non-potential market segments.

The curriculum developed by an educational institution should refer to the vision of the institution. This is true for the two research locations. The Vision of Postgraduate Program is shown at Table 4.

Table 4. The Vision of Postgraduate Program

\begin{tabular}{|l|l|}
\hline \multicolumn{3}{|c|}{ University Name /Vision } \\
\hline UIN MALIKI Malang & \multicolumn{2}{|c|}{ UNISMA Malang } \\
\hline Being a leading, & Making the Postgraduate \\
excellent and reputable & Program has high \\
study program in the & competitiveness, produce \\
Islamic University & graduates who can \\
environment, in the & discover and develop \\
development of Islamic & science and technology \\
religious education and & and culture through \\
has firmness of Aqeedah & education, research, and \\
and spiritual depth, & community services \\
nobleness of morality, & based on \\
breadth of knowledge & the Ahlusunnahwal \\
and professionalism. & Jamaan Islam. \\
\hline
\end{tabular}

These two visions referred to the opinions of Gabriel and Farmer (2009:53) stating that a compelling vision has to start with key ideas, values, and beliefs, can be reformulated in the following table:

Table 5. Indicator of Vision

\begin{tabular}{|l|l|l|}
\hline Indicator & $\begin{array}{l}\text { UIN MALIKI } \\
\text { Malang }\end{array}$ & \multicolumn{1}{|c|}{ UNISMA Malang } \\
\hline Key Ideas & $\begin{array}{l}\text { A leading, } \\
\text { ecxellent and } \\
\text { reputable study } \\
\text { program }\end{array}$ & $\begin{array}{l}\text { Highly competitive } \\
\text { Postgraduate Program }\end{array}$ \\
\hline Values & $\begin{array}{l}\text { Robustness of } \\
\text { Aqeedah and } \\
\text { spiritual depth, } \\
\text { nobleness of } \\
\text { character, } \\
\text { breadth of } \\
\text { knowledge and } \\
\text { professionalism }\end{array}$ & \\
Islamic Ahlusunnah wal \\
\hline Beliefs & $\begin{array}{l}\text { Development } \\
\text { of Islamic } \\
\text { Education }\end{array}$ & $\begin{array}{l}\text { Discovering } \\
\text { developing science and } \\
\text { technology and culture }\end{array}$ \\
\hline
\end{tabular}

The indicators in the table 5 show that the two postgraduates, in constructing their vision, they are in structure with the general rules. The coreideas and beliefs on the 
indicators are relatively the same. However, the indicators of values of UNISMA seem too general. They are different from UIN MALIKI, the indicators of values are revealed in great detail, namely: the firmness of Aqeedah and spiritual depth, nobleness of morality, breadth of knowledge and professionalism.

The vision cannot work when it is not revealed into a mission. The mission of the two institutions can be described in table 6 .

Table 6. Mission of Postgraduate Program

\begin{tabular}{|c|c|}
\hline \multicolumn{2}{|c|}{ University Name /Mission } \\
\hline UIN MALIKI Malang & UNISMA Malang \\
\hline $\begin{array}{l}\text { 1. Organizing the best } \\
\text { quality education in } \\
\text { order to educate and } \\
\text { empower the Islamic } \\
\text { community }\end{array}$ & $\begin{array}{l}\text { 1. Organizing } \\
\text { professional, } \\
\text { quality and } \\
\text { competitive master } \\
\text { and doctoral } \\
\text { programs at the } \\
\text { national and } \\
\text { international levels } \\
\text { to produce } \\
\text { graduates who has } \\
\text { quality, } \\
\text { competitive-ness, } \\
\text { and moral values } \\
\text { based on Islamic } \\
\text { AhlusunnahwalJa } \\
\text { maah }\end{array}$ \\
\hline $\begin{array}{l}\text { 2. Develop Islamic } \\
\text { education in } \\
\text { correspondent with } \\
\text { the demand of the } \\
\text { wider community }\end{array}$ & $\begin{array}{l}\text { 2. Developing } \\
\text { professional } \\
\text { research } \\
\text { practices and } \\
\text { produce } \\
\text { innovative work in } \\
\text { science, } \\
\text { technology, art } \\
\text { and culture that is } \\
\text { worthwhile to the } \\
\text { benefit of the } \\
\text { people }\end{array}$ \\
\hline $\begin{array}{l}\text { 3. Improving the } \\
\text { quality and quantity } \\
\text { of research in the } \\
\text { Islamic Education }\end{array}$ & $\begin{array}{l}\text { 3. Developing } \\
\text { research-based in } \\
\text { community } \\
\text { service in science } \\
\text { that has beneficial } \\
\text { factor to people } \\
\text { through an } \\
\text { interdisciplinary, } \\
\text { and trans- } \\
\text { disciplinary } \\
\text { approach }\end{array}$ \\
\hline $\begin{array}{l}\text { 4. Producing graduates } \\
\text { who have moral and }\end{array}$ & $\begin{array}{l}\text { 4. Developing } \\
\text { network }\end{array}$ \\
\hline
\end{tabular}

\begin{tabular}{|c|c|}
\hline $\begin{array}{l}\text { intellectual } \\
\text { responsibility in } \\
\text { developing Islamic } \\
\text { education }\end{array}$ & $\begin{array}{l}\text { partnerships that } \\
\text { synergize with } \\
\text { various parties to } \\
\text { improve the } \\
\text { implementation of } \\
\text { tri-dharma (the } \\
\text { three duties) of } \\
\text { university with a } \\
\text { good management } \\
\text { (good governance) } \\
\text { towards national } \\
\text { and international } \\
\text { standard graduate } \\
\text { program }\end{array}$ \\
\hline 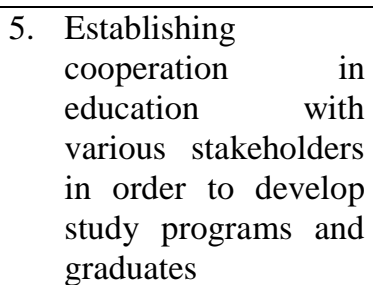 & \\
\hline
\end{tabular}

Adjusted into the Tri Dharma of University (Three Main Duties of University in Indonesia), table 6 can be described as follow:

Table 7. Adjustment of the Mission into the Tri Dharma of Postgraduates Program

\begin{tabular}{|c|c|c|}
\hline \multirow[b]{2}{*}{$\begin{array}{l}\text { Dharma of } \\
\text { University }\end{array}$} & \multicolumn{2}{|c|}{$\begin{array}{c}\text { University Name/ } \\
\text { Mission }\end{array}$} \\
\hline & $\begin{array}{c}\text { UIN } \\
\text { MALIKI } \\
\text { Malang }\end{array}$ & $\begin{array}{c}\text { UNISMA } \\
\text { Malang }\end{array}$ \\
\hline Pedagogy & $\checkmark$ & $\checkmark$ \\
\hline Research & $\checkmark$ & $\checkmark$ \\
\hline $\begin{array}{l}\text { Community } \\
\text { service }\end{array}$ & - & $\checkmark$ \\
\hline Cooperation & $\checkmark$ & $\checkmark$ \\
\hline
\end{tabular}

The table shows that UIN MALIKI Malang has no community service point. It is different from UNISMA Malang which fully implements the university dharma plus cooperation.

Gabriel and Farmer(2009)conclude that' the mission is the touch point that can help you determine whether what should be happening is happening." Missions can help people inside the organization to determine what should happen, and the reality that happens. The mission of the Master Program of PAI in UIN MALIKI strives to achieve 
the vision through organizing and developing education by research and collaboration in order to produce graduates who have high moral and intellectual standard.

The same thing was written in the UNISMA Malang postgraduate mission, but the different point was in the development of community services. In operation the mission, it is necessary to establish the objective of the institution. The postgraduate goals in both institutions can be seen as follow:

Table 8. Goals of Postgraduate Program

\begin{tabular}{|c|c|}
\hline \multicolumn{2}{|c|}{ University Name / Goals } \\
\hline UIN MALIKI Malang & UNISMA Malang \\
\hline $\begin{array}{l}\text { 1. Making graduates as } \\
\text { reliable researchers in } \\
\text { Islamic field and } \\
\text { religious education }\end{array}$ & $\begin{array}{l}\text { 1. Developing } \\
\text { science, } \\
\text { technology, art, } \\
\text { and culture in } \\
\text { order to improve } \\
\text { the living } \\
\text { standard of people } \\
\text { and community } \\
\text { benefit. }\end{array}$ \\
\hline $\begin{array}{l}\text { 2. Producing quality } \\
\text { and devout human } \\
\text { resources who are } \\
\text { able to compete in } \\
\text { the global era with a } \\
\text { tolerant and moderate } \\
\text { attitude }\end{array}$ & $\begin{array}{l}\text { 2. Producing quality } \\
\text { and devout human } \\
\text { resources who are } \\
\text { able to compete in } \\
\text { the global era } \\
\text { with a tolerant } \\
\text { and moderate } \\
\text { attitude }\end{array}$ \\
\hline $\begin{array}{l}\text { 3. Making the graduates } \\
\text { as reliable consultant } \\
\text { in the development of } \\
\text { Islamic education }\end{array}$ & $\begin{array}{l}\text { 4. Realizing the } \\
\text { Post-graduate } \\
\text { Program as } \\
\text { administrator } \\
\text { institutions of } \\
\text { master and } \\
\text { doctoral education } \\
\text { that are well- } \\
\text { manage (good } \\
\text { governance). }\end{array}$ \\
\hline $\begin{array}{l}\text { 4. Making the graduates } \\
\text { as an entrepreneur in } \\
\text { Islamic education }\end{array}$ & \\
\hline
\end{tabular}

UIN MALIKI Malang targets its graduates, while UNISMA Malang does not only focus on graduates but also on studies and the postgraduate program itself. UIN MALIKI Malang is oriented towards emphasizing the graduates produced, while UNISMA Malang is not only oriented towards graduates and study programs, but also the development of science, technology, art, and culture.

In developing the ability of master students, post-graduate programs compile the curriculum by classifying courses as follows:

Table 9: The Classification of Postgraduate Courses

\begin{tabular}{|ll|l|}
\hline \multicolumn{2}{|c|}{ UNIVERSITY NAME / COURSES } \\
\hline UIN MALIKI Malang & \multicolumn{1}{c|}{ UNISMA Malang } \\
\hline $\begin{array}{l}\text { Main Competence } \\
\text { Courses }\end{array}$ & $\begin{array}{l}\text { General Compulsory } \\
\text { Courses }\end{array}$ \\
\hline $\begin{array}{l}\text { Basic Competence } \\
\text { Courses }\end{array}$ & elective courses \\
\hline $\begin{array}{l}\text { Supporting Competence } \\
\text { Courses }\end{array}$ & Compulsory Courses \\
\hline $\begin{array}{l}\text { Main Competence } \\
\text { Courses }\end{array}$ & Basic Courses \\
\hline $\begin{array}{l}\text { Methodology } \\
\text { Competence Courses }\end{array}$ & - \\
\hline
\end{tabular}

The classification of the courses is in the context of achieving theoretical ability and professional practices in problem-solving using their knowledge. The three abilities, including theoretical ability, professional practice, and problem-solving in the framework of learning achievement of Indonesian National Qualification Framework (KKNI) at level 8, are:

1. Being able to develop knowledge, technology, and art in their knowledge area or professional practice through research, until producing innovative and proven work.

2. Being able to solve the problems of science, technology, and art in their scientific areas through inter or multidisciplinary approach.

3. Being able to manage research and development that have a benefit to society and science and able to obtain national and international recognition. (Dikti, 2014).

The learning achievements of the master program set by the government, are conceptualized in the implementations by the post-graduate institution through the classification of courses in table 9. 
Classification of the study program of an institution will be able to describe the achievement of the vision and mission. Below is an illustration of the percentage of each study program.

Table 10.Variant on the Total of Credit Based on Classification of Courses

\begin{tabular}{|c|c|c|c|c|c|}
\hline \multicolumn{3}{|c|}{ UIN MALIKI Malang } & \multicolumn{3}{|c|}{ UNISMA Malang } \\
\hline \multirow{2}{*}{$\begin{array}{c}\text { Courses } \\
\text { Group }\end{array}$} & \multicolumn{2}{|c|}{ Amount } & \multirow{2}{*}{$\begin{array}{l}\text { Courses } \\
\text { Group }\end{array}$} & \multicolumn{2}{|c|}{ Amount } \\
\hline & Credit & $\%$ & & Credit & $\%$ \\
\hline \begin{tabular}{|l|} 
Main \\
Competence \\
Courses \\
\end{tabular} & 21 & 33.3 & $\begin{array}{l}\text { General } \\
\text { Compulsory } \\
\text { Courses }\end{array}$ & 8 & 22.2 \\
\hline \begin{tabular}{|l|} 
Basic \\
Competence \\
Courses \\
\end{tabular} & 9 & 14.28 & $\begin{array}{l}\text { Elective } \\
\text { Courses }\end{array}$ & 5 & 13.8 \\
\hline \begin{tabular}{|l|} 
Supporting \\
Competency \\
Courses \\
\end{tabular} & 18 & 28.57 & $\begin{array}{l}\text { Compulsory } \\
\text { Courses }\end{array}$ & 17 & 47.2 \\
\hline $\begin{array}{l}\text { Methodology } \\
\text { Competence } \\
\text { Courses }\end{array}$ & 9 & 14.28 & $\begin{array}{l}\text { Basic } \\
\text { Courses }\end{array}$ & 6 & 16.6 \\
\hline Thesis & 6 & 9.5 & & & \\
\hline Total & 63 & 100 & & 36 & 100 \\
\hline
\end{tabular}

The percentage in Table 10 shows that in UIN MALIKI Malang, the course that is the basis for graduate development is called the Main Competence Course (MKU) with a total of 21 credits or $33.3 \%$. While UNISMA Malang has a Compulsory Course (MKW) with a total of 17 credits or $47.2 \%$.

The derivative course from the classification in table 10 can be explained as follow:

Table 11. Strengthening Research Methodologies

\begin{tabular}{|l|c|l|c|}
\hline $\begin{array}{c}\text { UIN MALIKI } \\
\text { Malang }\end{array}$ & Credit & $\begin{array}{l}\text { UNISMA } \\
\text { Malang }\end{array}$ & Credit \\
\hline $\begin{array}{l}\text { Thesis Research } \\
\text { Methodology }\end{array}$ & 3 & $\begin{array}{l}\text { Science } \\
\text { Philosophy }\end{array}$ & 2 \\
\hline $\begin{array}{l}\text { Proposal } \\
\text { Seminar }\end{array}$ & 0 & $\begin{array}{l}\text { Quantitative } \\
\text { Research } \\
\text { Methodology }\end{array}$ & 2 \\
\hline Thesis & 0 & $\begin{array}{l}\text { Qualitative } \\
\text { Research } \\
\text { Methodology }\end{array}$ & 2 \\
\hline & $\begin{array}{l}\text { Independent } \\
\text { Study/ } \\
\text { Proposal } \\
\text { Seminar }\end{array}$ & 2 \\
\hline Total & 9 & Thesis & 6 \\
\hline
\end{tabular}

The subject of strengthening research capabilities in table 11 shows the realization of the post-graduates' vision and mission, related to the statement: developing research and professional practice to create innovative work in science, technology, art, and culture as well as increasing quantity and quality of the research. UNISMA carries out its implementation through more research subjects than UIN MALIKI Malang. UNISMA has 4 credits related to Quantitative Research Methodology and Qualitative Research Methodology based on the philosophy of science. It is consistent with Smith's opinion cited by (University of Wolferhampton, 2011), which states that post-graduate education should be "producing people with the necessary balance of skills to conduct high-quality research and development in industry, universities and the public sector. Postgraduate education must have a balance of high-quality research and development skill in the industry, universities, and the public.

The further emphasized by Department for Business Innovation \& Skills, (2009) states that post-graduate qualifications, both from taught and research courses, are increasingly a necessity for careers in the public and private sectors alike. Theory and research courses are critical in the postgraduate course so that graduates can develop knowledge and be accepted in all public sectors.

The variation of the research courses explained meets the curriculum standards set by the government, which is a curriculum based on Indonesia National Framework of Qualifications (Kerangka Kualifikasi Nasional Indonesia = KKNI). The curriculum is based on the framework of master graduates' achievement, who are demanded to be able to manage research and development that is beneficial to people and science, and able to obtain national and international recognition (KEMENRISTEKDIKTI, 2017).

The research and development should be implemented in practice through Thesis 
subject. Whether or not this implementation, it has not been reviewed in this study. However, the combination of these courses tried to bridge what Phan, (2015) said that some of the problems faced by University, for example, the mismatch between traditional views of knowledge versus contemporary objectives of the curriculum, the recent institutional autonomy agreement versus stakeholder competence, and innovative ideas versus traditional values.

The synergy between the two viewpoints can be obtained through works of research in research methodology courses. Post-graduate studies are not solely oriented to classical science but also to the contemporary one. These two orientations require knowledge of tools in the form of a foreign language which is provided to students. In the two postgraduate programs, foreign language subject can be described as follows:

Table 12. Foreign Language Acquisition

\begin{tabular}{|l|c|l|c|}
\hline \multicolumn{1}{|c|}{$\begin{array}{c}\text { UIN Maliki } \\
\text { Malang }\end{array}$} & Credit & $\begin{array}{c}\text { UNISMA } \\
\text { Malang }\end{array}$ & Credit \\
\hline $\begin{array}{l}\text { English for } \\
\text { Islamic Study }\end{array}$ & 0 & English & 1 \\
\hline & & $\begin{array}{l}\text { Arab } \\
\text { Language }\end{array}$ & 1 \\
\hline Total & 0 & Total & 2 \\
\hline
\end{tabular}

The table above shows that there are more foreign language courses at UNISMA Malang postgraduate programs (English and Arabic courses) than UIN MALIKI Malang (English courses). Foreign language acquisition can certify post-graduate student in studying process independently. It is because the ability of foreign language acquisition can be used for understanding classical and contemporary texts on education and learning process.

In the framework of actualizing the vision and mission related to the public demand and Islamic studies with an interdisciplinary and trans-disciplinary approach, it is implemented the following courses:
Table 13.Islamic Studies Expertise

\begin{tabular}{|l|c|l|c|}
\hline $\begin{array}{l}\text { UIN MALIKI } \\
\text { Malang }\end{array}$ & Credit & $\begin{array}{l}\text { UNISMA } \\
\text { Malang }\end{array}$ & Credit \\
\hline $\begin{array}{l}\text { Study of } \\
\text { Qurán }\end{array}$ & 3 & $\begin{array}{l}\text { Study of Al } \\
\text { Qurán }\end{array}$ & 1 \\
\hline $\begin{array}{l}\text { Study of } \\
\text { Hadith }\end{array}$ & 3 & $\begin{array}{l}\text { Study of Al } \\
\text { Hadits }\end{array}$ & 1 \\
\hline $\begin{array}{l}\text { Study of } \\
\text { Islamic } \\
\text { Civilization }\end{array}$ & 3 & $\begin{array}{l}\text { History of } \\
\text { Islamic } \\
\text { Civilization } \\
\text { and } \\
\text { Intellectual }\end{array}$ & 3 \\
\hline $\begin{array}{l}\text { Study of } \\
\text { Islamic } \\
\text { Approach }\end{array}$ & 3 & $\begin{array}{l}\text { Methodology/ } \\
\text { Approach of } \\
\text { Islamic Study }\end{array}$ & 2 \\
\hline $\begin{array}{l}\text { Study of } \\
\text { Integration } \\
\text { Islam and } \\
\text { Science }\end{array}$ & 3 & $\begin{array}{l}\text { Information } \\
\text { and } \\
\text { Technology }\end{array}$ & 1 \\
\hline $\begin{array}{l}\text { Islamic } \\
\text { Philosophy } \\
\text { and Tasawuf }\end{array}$ & 3 & Tasawuf & 2 \\
\hline $\begin{array}{l}\text { Fiqh } \\
\text { UshulFiqh }\end{array}$ & 3 & Total & 10 \\
\hline $\begin{array}{l}\text { Contemporary } \\
\text { Fiqh Study }\end{array}$ & 3 & 0 \\
\hline Total & & \\
\hline
\end{tabular}

Islamic Studies courses at UIN MALIKI Malang indicate its in line direction with the vision and mission compared to UNISMA Malang. The existence of Islamic Integration Studies, Science Fiqh-UshulFiqh studies, and Contemporary Fiqh Studies directs students to think and act tolerantly and multiculturally. Such a curriculum development is in accordance with (Patrick, 2006) stating that the need to understand the curriculum concerning theology, race, and ethnicity, multicultural studies, global economics and trade, ecology, gender and sexuality, and social and political rearrangement must be enlarged.

However, from the scope of PAI which encompasses: Al Quran - Hadith, Aqeedah Akhlaq, Fiqh, and The History of Islamic Civilization, it can be stated that the two postgraduate, as this research sites, still do not support the strengthening of content knowledge of PAI teachers who continue further study. Reinforcement according to the scope can be made as follow: 
Table 14. Qurándan Hadith

\begin{tabular}{|l|l|c|c|c|}
\hline Courses & $\begin{array}{l}\text { UIN } \\
\text { MALIKI } \\
\text { Malang }\end{array}$ & Credit & $\begin{array}{l}\text { UNISMA } \\
\text { Malang }\end{array}$ & Credit \\
\hline $\begin{array}{l}\text { Qurán } \\
\text { and } \\
\text { Hadith }\end{array}$ & $\begin{array}{l}\text { Study of } \\
\text { Al Qurán }\end{array}$ & 3 & $\begin{array}{l}\text { Study of } \\
\text { Al Qurán }\end{array}$ & 1 \\
\hline & $\begin{array}{l}\text { Study of } \\
\text { Al Hadits }\end{array}$ & 3 & $\begin{array}{l}\text { Study of } \\
\text { Al Hadits }\end{array}$ & 1 \\
\hline & Total & 6 & Total & 2 \\
\hline
\end{tabular}

Reinforcement in the content of Qur'an and Hadith is mostly carried out by the postgraduate of UIN MALIKI Malang. It does not happen in the content reinforcement of the History of Islamic Civilization. The number of credits between the two postgraduate programs is alike. The picture is as follows:

Table 15. Reinforcement of the History of Islamic Civilization

\begin{tabular}{|c|c|c|c|c|}
\hline Courses & $\begin{array}{c}\text { UIN } \\
\text { MALIKI } \\
\text { Malang } \\
\end{array}$ & Credit & $\begin{array}{c}\text { UNISMA } \\
\text { Malang }\end{array}$ & Credit \\
\hline \multirow[t]{2}{*}{$\begin{array}{l}\text { History } \\
\text { of } \\
\text { Islamic } \\
\text { Civilizati } \\
\text { on }\end{array}$} & $\begin{array}{l}\text { Study of } \\
\text { Islamic } \\
\text { Civilization }\end{array}$ & 3 & $\begin{array}{l}\text { Islamic } \\
\text { Civilization } \\
\text { History and } \\
\text { Intellectual }\end{array}$ & 3 \\
\hline & Total & 3 & Total & 3 \\
\hline
\end{tabular}

The balance only occurs history courses. There is a difference in the Reinforcement of AqeedahAkhlaq, and the explanation is as follows:

Table 16.The reinforcement of Aqeedah and

\begin{tabular}{|c|c|c|c|c|}
\hline \multicolumn{5}{|c|}{ Akhlaq } \\
\hline $\begin{array}{l}\text { Courses/ } \\
\text { Subjects }\end{array}$ & $\begin{array}{c}\text { UIN MALIKI } \\
\text { Malang }\end{array}$ & Credit & $\begin{array}{c}\text { UNISMA } \\
\text { Malang }\end{array}$ & Credit \\
\hline \multirow[t]{4}{*}{$\begin{array}{l}\text { Aqeedah } \\
\text { Akhlaq }\end{array}$} & $\begin{array}{l}\text { Islamic Study } \\
\text { approach }\end{array}$ & 3 & $\begin{array}{l}\text { Methodolo } \\
\text { gy/ } \\
\text { Approach } \\
\text { of Islamic } \\
\text { Study }\end{array}$ & 2 \\
\hline & $\begin{array}{l}\text { Islamic } \\
\text { Philosophy } \\
\text { danTasawuf }\end{array}$ & 3 & Tasawuf & 2 \\
\hline & $\begin{array}{lr}\text { Study } & \text { of } \\
\text { Integration of } \\
\text { Islam and } \\
\text { Science }\end{array}$ & 3 & & 0 \\
\hline & Total & 9 & Total & 4 \\
\hline
\end{tabular}

Content reinforcement of Aqeedah Akhlaq is still mostly carried out by postgraduate program of UIN Maulana Malik Ibrahim Malang. It has also happened to the Fiqh content, UNISMA Malang shows nothing. Here is the description:

Table 17. Fiqh

\begin{tabular}{|l|l|c|c|c|}
\hline \multirow{2}{*}{ Courses } & \multicolumn{1}{|c|}{$\begin{array}{c}\text { UIN } \\
\text { MALIKI } \\
\text { Malang }\end{array}$} & Credit & $\begin{array}{c}\text { UNISMA } \\
\text { Malang }\end{array}$ & Credit \\
\hline Fiqh & $\begin{array}{l}\text { Fiqh - } \\
\text { UshulFiqh }\end{array}$ & 3 & & 0 \\
\cline { 2 - 5 } & $\begin{array}{l}\text { Study of } \\
\text { Contempo } \\
\text { rary Fiqh }\end{array}$ & 3 & & 0 \\
\cline { 2 - 5 } & Total & 6 & & 0 \\
\hline
\end{tabular}

The strengthening of content knowledge is dominantly carried out by the postgraduate program of UIN MALIKI Malang compared to UNISMA Malang. What was done by UIN MALIKI Malang is an effort to repair the weakness of this side during their PAI undergraduate study program.

According to the nomenclature, PAI master program requires courses that support the achievement of study and practice of education. Education and Learning Curriculum can be described as follows:

Table 18. Education Strengthening

\begin{tabular}{|l|c|l|c|}
\hline $\begin{array}{l}\text { UIN MALIKI } \\
\text { Malang }\end{array}$ & Credit & $\begin{array}{l}\text { UNISMA } \\
\text { Malang }\end{array}$ & Credit \\
\hline $\begin{array}{l}\text { PAI Curriculum } \\
\text { Development }\end{array}$ & 3 & $\begin{array}{l}\text { Managem } \\
\text { ent of } \\
\text { Islamic } \\
\text { Education }\end{array}$ & 2 \\
\hline $\begin{array}{l}\text { Development of } \\
\text { Methodology } \\
\text { PAI Learning }\end{array}$ & 3 & $\begin{array}{l}\text { Evaluatio } \\
\text { n of } \\
\text { Islamic } \\
\text { Education } \\
\text { Program }\end{array}$ & 2 \\
\hline $\begin{array}{l}\text { Development of } \\
\text { Media Learning } \\
\text { for PAI }\end{array}$ & 3 & $\begin{array}{l}\text { Technolog } \\
\text { y of } \\
\text { Islamic } \\
\text { learning }\end{array}$ & 2 \\
\hline $\begin{array}{l}\text { Evaluation } \\
\text { Perfection of } \\
\text { PAI Learning }\end{array}$ & 3 & $\begin{array}{l}\text { Islamic } \\
\text { Education } \\
\text { Philosoph } \\
\text { y }\end{array}$ & 2 \\
\hline $\begin{array}{l}\text { Islamic } \\
\text { Education } \\
\text { Philosophy }\end{array}$ & 3 & $\begin{array}{l}\text { Sociology } \\
\text { of Islamic } \\
\text { Education }\end{array}$ & 2 \\
\hline
\end{tabular}




\begin{tabular}{|l|c|c|c|}
\hline $\begin{array}{l}\text { Social History } \\
\text { of Islamic } \\
\text { Education }\end{array}$ & 3 & & 0 \\
\hline $\begin{array}{l}\text { Study of PAI } \\
\text { Policy }\end{array}$ & 3 & & 0 \\
\hline $\begin{array}{l}\text { Quality } \\
\text { assurance } \\
\text { System of PAI }\end{array}$ & 3 & & 0 \\
\hline $\begin{array}{l}\text { PAI Study at } \\
\text { School, } \\
\text { Madrasas and } \\
\text { University/Coll } \\
\text { ege }\end{array}$ & 3 & & 0 \\
\hline $\begin{array}{l}\text { Islamic } \\
\text { Education Ideas }\end{array}$ & 3 & & 0 \\
\hline Total & 30 & & 10 \\
\hline
\end{tabular}

The table above shows that the postgraduate of UIN MALIKI Malang provides pedagogical content knowledge (PCK) or education and learning much more than UNISMA Malang. It means that postgraduate is more identical in preparing to strengthen how a teacher teaches in class, but it is influential in its development through research subjects. Besides, from table 13 and 14 , both postgraduate programs are weak in providing content knowledge reinforcement.

The inherent characteristic of master graduates in knowledge in the level of workability is to develop science and technology through inter /multidisciplinary research, innovation, and reviewed. Besides, with the existing curriculum, it can realize the skills embodied in KKNI with general skills:

1. Being able to develop logical, critical, systematic, and creative thinking through scientific research, designs creation and artworks in science and technology area that concern with applying humanities values in accordance with their expertise, compile scientific conceptions and its result studies in the form of a thesis published in an accredited scientific journal;

2. Being able to carry out academic validation or study based on their expertise in solving problems in the relevant society and industry through the development of their knowledge and expertise;

3. Being able to arrange ideas, brainstorming, and scientific arguments responsibly and built upon academic ethics, and also communicate it through the media to the academic community and the public;

4. Being able to identify the scientific scope that becomes the object of research and position it into a research map developed through an inter or multidisciplinary approach;

5. Being able to take decisions in the context of solving the problems in science and technology development that concern with applying humanities values based on analytical or experimental studies on information and data;

6. Being able to manage, develop and maintain a network within colleagues in workplace, institution, and broader research community;

7. Being able to increase the learning capacity independently;

8. Being able to document, store, secure, and rediscover research data in order to ensure validity and prevent plagiarism; (Ditjen Belmawa, 2014).

The explanation above shows that the curriculum of the Master Program in Islamic Religious Education at UIN MALIKI Malang and Unisma Malang has a construction based on grouping the subjects according to the requirement of Indonesia's National qualification framework at level 8 . The content of its curriculum is dominant in mastering pedagogical content knowledge (PCK). This mastery tends not to lessen the weaknesses of PAI graduates in content knowledge. The two graduate programs do not provide elective courses at all. Following the perspective of accreditation standard 5, the provision of elective courses is an implementation of curriculum flexibility. It will have an impact on the two postgraduates' accreditation assessment. Also, elective courses are a form of 
flexibility in implementing the curriculum. Zheng, (2011) states that Elastic and flexible way of education will be adopted to cultivate flexible talents adapting to modern social needs.

An elastic and flexible curriculum can create students and alumni that is able to adapt to modern social needs. The flexibility of elective courses in the two postgraduate programs does not have a credit because there are no elective courses provided (Badan Akreditasi Nasional Perguruan Tinggi, 2009). The flexibility, according to
Ameyaw et al.(2017) is as a responsive curriculum. This curriculum is created in order to meet the changing needs of students, bridges the gap between universal knowledge and theory, on the one hand, and contextual, the ever-changing reality of everyday life and working work, on the other. In the framework of developing tertiary education, especially postgraduate, it is necessary to, at least, refer to the designs made byCarnel and Fung(2017) which are referred to as the Connected Curriculum:

Figure 1. The Connected Curriculum Framework

Fig. 1 shows that the curriculum needs to have $\mathrm{s}$ constructive dialogue about how undergraduate and graduate programs are as a continuous entity. This Curriculum Model is designed in order that students learn through research and inquiry. Learning is supported by connecting students with the output to be achieved, the workplace, alumni, cross-study program, research activities and research institutions. The results of the study stated that the main issues related to the success of the master's program include (1) clarity of objectives, (2) extensive research on future competency needs, (3) a committed and strongly led development team, (4) a comprehensive network with key players in the field of competence, and (5) thorough documentation of the entire process as a basis for sustainable development (Ojasalo, 2012). Thus, the tension between standardization and contextualization in curriculum development can be understood as the stage of developing curriculum harmonization in which two domains appear: 1) Differences in ideas about what curriculum harmonization means for the current curriculum and 2) Inconsistency between educational principles and the reality of training (van der Aa et al., 2019).

The results of the research mention some main foundations of the curriculum for the doctoral program of the educational technology study program: (1) adjustment and strengthening of the philosophy of lifebased learning (KBK); (2) implementing the conception of national education from $\mathrm{Ki}$ Hadjar Dewantara (KHD); (3) adjustment and strengthening of the content of the main elements of the Association of Educational, Communication, and Technology (AECT) paradigm; (4) based on the development of higher education standards and the Indonesian National Qualifications Framework (KKNI); (5) in accordance with the provisions and guidelines for the implementation of the study program Association of Indonesian Education Technology Study Programs (APS-TPI); and (6) emphasizing the development, 
strengthening, and development of professional ethics and noble character of Indonesia for the education of the $21 \mathrm{st}$ century millennial generation, as well as strengthening the adaptation and capability of graduates in the digital era and the era of 21st century technological disruption(Suryati et al., 2020). Some of things above should be a reference for postgraduate policy makers, especially at the master's program level. With the hope that the curriculum is implemented and developed in accordance with the demands of the times while at the same time answering various existing problems.

\section{CONCLUSION}

The curriculum construction of the Master Program in Islamic Religious Education at UIN Maulana Malik Ibrahim and UNISMA Malang is based on the grouping of subjects according to the demands of the Indonesian National Qualification Framework at level 8. The dominant curriculum content is in mastering pedagogical content knowledge (PCK) compared to the content knowledge (CK). Mastery of the pedagogical content knowledge (PCK) tends not to reduce the weaknesses of PAI graduates in content knowledge (CK). Besides, there is no flexibility in the curriculum because of no elective courses for post-graduate students.

\section{REFERENCES}

Ameyaw, J., Turnhout, E., Arts, B., \& Wals, A. (2017). Creating a responsive curriculum for postgraduates: lessons from a case in Ghana. Journal of Further and Higher Education,. Journal of Further and Higher Education.

Anwar, S., \& Mathew, S. K. (2014). The Contribution of ICT in Higher Education: a multifaceted approach. IOSR Journal of Electronics and Communication Engineering, 9(1), 6063.

Badan Akreditasi Nasional Perguruan Tinggi. (2009). Buku VI Matriks Penilaian Instrumen Akreditasi
Program Studi Magister. Badan Akreditasi Nasional Perguruan Tinggi.

Beigi, F. H., Keramati, M. R., \& Ahmadi, A. (2011). The quality curriculum evaluation in postgraduate studies of Educational Management and Planning in the public Universities of Tehran City _ Elsevier Enhanced Reader.pdf. Proceedia Social and Behavioral Sciences, 3723-3730.

Carnell, B., \& Fung, D. (2017). Developing the Higher Education Curriculum Research-based Education in Practice. UCL Press.

Department for Business Innovation \& Skills. (2009). The future of universities in a knowledge economy. Department for Business Innovation \& Skills.

Dikti, T. K. B. (2014). Capaian Pembelajaran Lulusan Program Studi. Dirjen Pendis. (2010). Analisis Deskriptif

Guru Pendidikan Agama Islam Pada Sekolah Tahun Pelajaran 2009-2010. Direktora Jenderal Pendidikan Islam. http://pendis.kemenag.go.id/file/dokum en/booklet091002.pdf

Ditjen Belmawa. (2014). Panduan Penyusunan Capaian Pembelajaran Lulusan Program Studi. Direktorat Pembelajaran Dan Kemahasiswaan, Direktorat Jenderal Pendidikan Tinggi, Kementerian Pendidikan Dan Kebudayaan.

Gabriel, John G; Farmer, C. P. (2009). ). How to Help Your School Thrive Without Breaking the Bank. Association for Supervision and Curriculum Development.

Hughes, J., \& Tan, E. (2012). The Dynamic Curriculum: shared experiences of ongoing curricular change in higher education. Dublin City University.

KEMENRISTEKDIKTI, T. P. K. P. T. (2017). KKNI dan SN-DIKTI. 1-17.

Kementerian Agama. (2008). Guru Depag Belum Penuhi Standar Kualifikasi. https://kemenag.go.id/read/guru-depagbelum-penuhi-standar-kualifikasi-vvj7 
Munadi, M. (2017a). Pendidikan Guru Agama Islam Di Perguruan Tinggi Umum Negeri (Studi Komparatif Antara Universitas Negeri Jakarta (UNJ) Dengan Universitas Pendidikan Indonesia (UPI) Bandung). Cendekia, 15(1).

Munadi, M. (2017b). The Content Mastery among Islamic Education Teachers in Junior Islamic Secondary Schools in Surakarta. Al-Ta Lim Journal, 24(2), 130-141. https://doi.org/10.15548/jt.v24i2.274

Ojasalo, K. (2012). Designing and implementing an innovative master's degree programme: a case study. International Journal on New Trends in Education and Their Implications, 3(3), 136-147.

Patrick, S. (2006). Curriculum Development in the Postmodern Era. Routledge.

Phan, T. N. (2015). Approaches To Curriculum Development In Vietnamese Higher Education: A Case Study. Centre For Learning Innovation Faculty Of Education Queensland University Of Technology.

Pyla, A. (2012). ICT as a Change Agent for Higher Education and Society. International Journal of Computer Applications, 1, 25-30.

Suryati, N., Kuswandi, D., Setyosari, P., Hutkemri, Chusniyah, T., Diana, R. C., \& Nurdiansa, E. S. (2020). Curriculum Development of Postgraduate Study
Program Based on Life-Based Learning Philosophy and Disruption Technology. 508(Icite), 434-436. https://doi.org/10.2991/assehr.k.201214. 273

Suwendi. (2019). Menjaga Khittah PTKI Melalui UM-PTKIN. Kemenag RI. https://kemenag.go.id/read/menjagakhittah-ptki-melalui-um-ptkin-6751x University of Wolferhampton. (2011). Curriculum Design And Pedagogic Principles For Postgraduate Education. University of Wolferhampton.

van der Aa, J. E., Scheele, F., Goverde, A. J., \& Teunissen, P. W. (2019). A qualitative study on harmonization of postgraduate medical education in Europe: negotiating flexibility is key. Perspectives on Medical Education, 8(4), 216-222. https://doi.org/10.1007/s40037-0190523-4

Widodo, A. (2013). Pengembangan kurikulum magister pendidikan biologi berdasarkan needs assessment, masukan stakeholder dan benchmarking. Universitas Pendidikan Indonesia.

Zheng, L. (2011). The Design of " $1+\mathrm{N}$ " Curriculum under Flexible Education Perspective. International Conference on Advances in Education and Management. ISAEBD 2011: Advances in Education and Management, 462468. 